\title{
Assessment of Wave Disturbance and Ship Motion for the Detailed Design of Hambantota Seaport
}

\author{
T. D.T.Pemasiri, K. Ramachandran, K. Thulasikopan, K.P.P.Pathirana, and \\ K. Raveenthiran
}

\begin{abstract}
This paper describes the 3D physical model for the proposed Hambantota harbour. The main objective of the physical model study is to assess the harbour tranquillity for different incident wave conditions which are expected to prevail at the site during harbour operations. It encompasses the assessment of wave disturbance within the harbour basin especially near the quay walls for assuring of safer ship motion and convenient ship operations and there by, to verify the adequacy and effectiveness of the harbour layout proposed for Hambantota harbour. The proposed harbour layout was subjected to several representative wave conditions in order to examine the wave penetration into the harbour basin and disturbance in front of the quay walls. In addition, movements of fully loaded ships were measured by mooring at various berth locations. Results for wave penetration were checked with mathematical model results. Ship motion results were compared with PIANC criteria. Both wave disturbance and ship motion results were within the acceptable limits.
\end{abstract}

Keywords: Wave disturbance, ship motion, model scale, prototype

\section{Introduction}

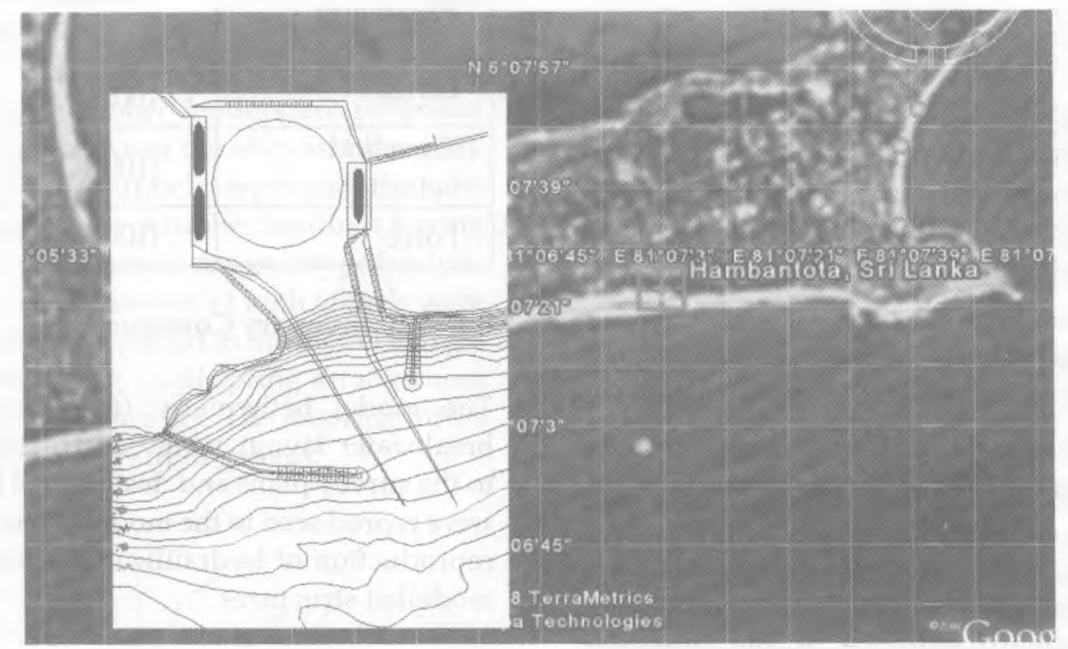

Figure 1 - Proposed Harbour

Sri Lanka occupies a strategic position along the main shipping route connecting Asia with Europe and America, and needs a major seaport to attract the international shipping industry. The Colombo Port even with the impending southward expansion will not be able to cater for the high demand within the region in years to come. Government of Sri Lanka has planned to develop the existing Galle Port as a regional port and identified the Hambantota site as for a major seaport. Two alternative options for development of a seaport at Hambantota were considered, and the one which the inland
Eng. T.D.T.Pemasiri, C. Eng., MIE(Sri Lnuka), B.Sc. Eng (Hons) (Moratuzva), M.Sc. (AIT), Research Engineer, Lanka Hydrawic listitute.

Eng. K. Ramachandran, AMIE(Sri Lanka), B.Sc. Eng. (Hons) (Rwhuma), Research Engineer, Lanka Hydranlic Institute.

Eng, K. Thulasikopun, AMIE(Sri Imika), B.Sc. Eng. (Hons) (Peralleniya), Research Engineer, Lanka Hydraulic institute.

Eng. (Dr.) K. P.P.Pathirana B.Sc. Eng. (Hons) (Perndeniya), M.Eng., Dr. Eng., C.Eng., FIE(Sri Lanka), MICE(London), Senior Lechurer, Departnent of Cinil Engineering, University of Peradenilya.

Dr. K. Raveenthirall B.Sc. Eng. (Hors) (Peradchiyn), M.Eng. (AlT), Dr. Eng. (Tohyo), Selnior Resenrch Engineer, Lanka Hydrnulic Institute. 
port within a part within a part of Karagan Lewaya Lagoon with an entrance from the sea immediately westward of the Hambantota headland (Figure 1) was considered as the best option. The feasibility studies were carried out during 2002 to 2006. In 2006 October, Memorandum of Understanding (MOU) between Sri Lanka Ports Authority (SLPA), and a consortium comprising China Harbour Engineering Company (CHEC) concerning the detailed design studies of Hambantota Seaport Development - Phase I Project was signed. As a sub consultant, Lanka Hydraulic Institute Ltd (LHI) undertook hydraulic studies, which include the field investigations, mathematical modelling and physical modelling to optimise the functional and operational efficiency of the newly developed port layout. The main facilities to be constructed in the Phase I includes:

- One way approach channel of $210 \mathrm{~m}$ wide

- Turning basin with a diameter of $600 \mathrm{~m}$

- Two general berths of $600 \mathrm{~m}$ long

- $\quad$ One oil berth of $310 \mathrm{~m}$ long

All these components are at $16 \mathrm{~m}$ MSL depth. This paper describes the three dimensional physical model studies to verify the adequacy of the proposed harbour layout by testing wave disturbance within the basin area and movements of moored ships at both berth locations and to optimise the layout.

\section{Model Setup}

Selection of a model scale for the proposed study was based on the following considerations:

- Entire basin area of the Hambantota harbour and navigation channel leading to southern entrance of the proposed harbour should be represented in the model.

- Waves need to be generated in the model with sufficient distance away from the harbour entrance in order to ensure full development of waves by the time they reach the area of interest. The distance also varies according to the combinations of wave heights, wave periods and directions considered.

- $\quad$ Size of the model basin at LHI $(35 \mathrm{~m} \times 25 \mathrm{~m})$
Considering these aspects, an undistorted model with a scale of 1:100 was selected for this study. For flows with a free surface, inertia and gravity forces are usually dominant and hence, the requirement for hydrodynamic similitude between the model and the prototype is the Froude similarity [6]. It is given below;

$$
\begin{aligned}
& (F r)_{\text {model }}=(F r)_{\text {prototype }} \\
& \left(\frac{V}{\sqrt{g d}}\right)_{m}=\left(\frac{V}{\sqrt{g d}}\right)_{p}
\end{aligned}
$$

Where, $d$ is the water depth, $g$ is the gravitational acceleration, $V$ is the celerity of wave front and the subscripts $m$ and $p$, denote the model and the prototype respectively. The similitude ratios obtained in this way for the main model parameters are given in Table 1.

Table 1 - Similitude ratios for the model parameters

\begin{tabular}{|l|l|}
\hline Parameter & \multicolumn{1}{|c|}{$\begin{array}{c}\text { Scale (model } \\
\text { prototype) }\end{array}$} \\
\hline Length & $1: 100$ \\
\hline $\begin{array}{l}\text { Time and } \\
\text { velocity }\end{array}$ & $1:(100)^{1 / 2}=1: 10$ \\
\hline Force & $1:(100)^{3}=1: 1000000$ \\
\hline
\end{tabular}

\subsection{Bathymetry Construction}

The model bathymetry (fixed bed) and the breakwater layout were constructed according to the survey plans and designs. All breakwaters were reproduced in the model to ensure a correct reproduction of hydraulic characteristics of the modelled structures.

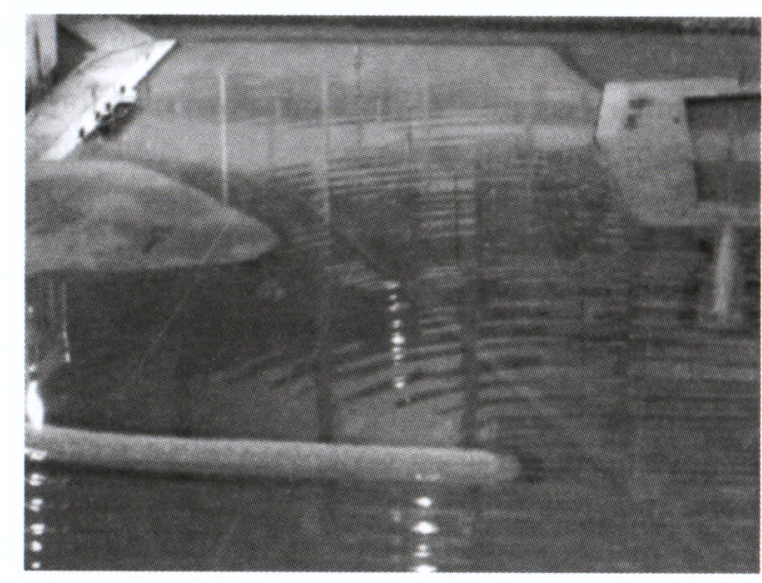

Figure 2 - Physical Model Testing 
The artificial concrete armour units (CHINESEP ODE) were used for main breakwater and rock armours for secondary breakwater which are $950 \mathrm{~m}$ and $310 \mathrm{~m}$ long respectively (Figure 2). Two separate quay walls are proposed for the harbour, one is $600 \mathrm{~m}$ long and for berthing of general cargo vessels and the other one is used as the oil terminal which is $310 \mathrm{~m}$ long. These are constructed using hollow concrete caissons with rock fill material. The top elevation of the quay walls is set at $4.0 \mathrm{~m}$ above MSL. Bollards in the general purpose berth were fixed at a spacing of $30 \mathrm{~m}$ whereas at the oil terminal, bollard spacing varies between $45 \mathrm{~m}$ and $90 \mathrm{~m}$. Rubber fenders were placed at every $15 \mathrm{~m}$ interval at both berths

\subsection{Ship Motion}

Two types of vessels were used in the model tests to represent $200 \mathrm{~m}$ cargo vessel and $230 \mathrm{~m}$ oil tanker that are expected to use the facility. Ballasting procedures equating for dead weight tonnage, metacentric height and roll period were carried out for both vessels prior to the testing [2].

Bridgestone type rubber fenders are proposed for the interface between the ship and the quay wall. They were accurately represented in the model by using pieces of rubber beadings having similar elastic properties as the prototy pefenders. The mooring arrangements of both vessels were also reasonably represented in the model using a combination of string - coil spring arrangement for model mooring lines [1]. The mooring forces were measured using strain gauges.

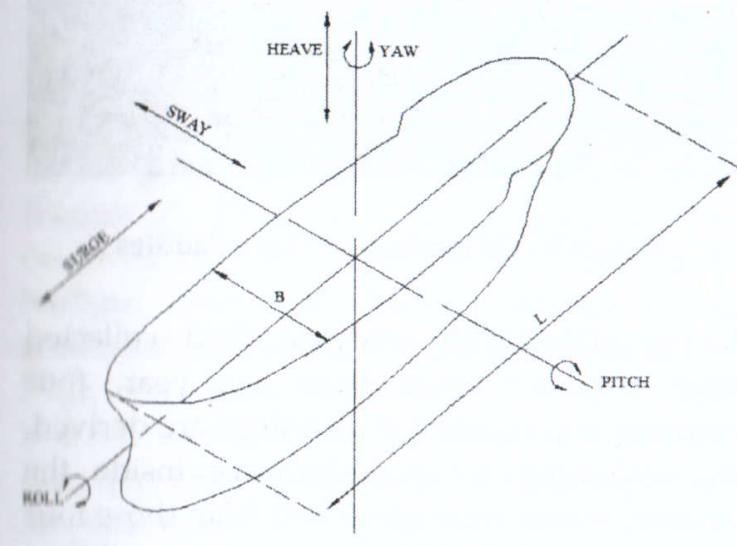

Figure 3 - Components of Ship Movement
Under the impact of waves, wind and currents, a moored ship is in continuous movement. The magnitude of the movement varies over a wide range, and mainly depends on the magnitude and direction of waves and winds. There are six components of ship movements as shown in Figure 3.

The ship movements can be defined as follows:

- Translatory Movements:

- $\quad$ Surge - Linear motion along the longitudinal axis of the vessel on a horizontal plane

- $\quad$ Sway - Linear motion along the transverse axis of the vessel on a horizontal plane

- Heave-Vertical up and down motion

- Rotational Movements:

- $\quad$ Roll - Rotary motion about vessel's longitudinal axis

- $\quad$ Pitch - Rotary motion about the vessel's transverse axis

- Yaw - Horizontal plane rotary motion about the vertical axis

In general, the movement of a ship will be a combination of more than one of the six movements described above. The movements in the horizontal plane, surge, sway and yaw, are influenced mainly by the fender and mooring systems that counteract the movements, where as the movements in the vertical plane, roll, pitch and heave, cannot be influenced appreciably by moorings and fenders [1].

The translatory and rotational movements of the moored ship are computed by measuring the movements at six locations, which are indicated in the above figure as V1, V2, V3, V4, V5 and V6. The ship movements referred in this report are defined in the following formulae;

$$
\begin{aligned}
\text { Surge } & =V 1[\mathrm{~m}] \\
\text { Sway } & =\frac{(V 5+V 6)}{2}[\mathrm{~m}] \\
\text { Heave } & =\frac{(V 2+V 3)}{2}[\mathrm{~m}] \\
\text { Roll } & =\frac{(V 2-V 3)}{B} * \frac{180^{\circ}}{\pi} \\
\text { Pitch } & =\left[\frac{1}{2}\left(V_{2}+V_{3}\right)-V_{4}\right] \frac{1}{L_{1}}\left(\frac{180^{\circ}}{\pi}\right) \\
\text { Yaw } & =\frac{(V 5-V 6)}{L} * \frac{180^{\circ}}{\pi}
\end{aligned}
$$


Table 2 - Recommended ship movement criteria for safe working conditions

\begin{tabular}{|c|c|c|c|c|c|c|c|}
\hline Ship type & $\begin{array}{l}\text { Cargo handling } \\
\text { equipment }\end{array}$ & $\begin{array}{l}\text { Surge } \\
\text { (m) }\end{array}$ & $\begin{array}{l}\text { Sway } \\
\text { (m) }\end{array}$ & $\begin{array}{l}\text { Heave } \\
\text { (m) }\end{array}$ & $\begin{array}{c}\text { Yaw } \\
\left({ }^{\circ}\right)\end{array}$ & $\begin{array}{l}\text { Pitch } \\
\text { (o) }\end{array}$ & $\begin{array}{c}\text { Roll } \\
\left({ }^{\circ}\right)\end{array}$ \\
\hline General cargo & - & 2.0 & 1.5 & 1.0 & 3 & 2 & 3 \\
\hline $\begin{array}{l}\text { Container } \\
\text { vessels }\end{array}$ & $\begin{array}{l}100 \% \text { efficiency } \\
50 \% \text { efficiency }\end{array}$ & $\begin{array}{l}1.0 \\
2.0\end{array}$ & $\begin{array}{l}0.6 \\
1.2 \\
\end{array}$ & $\begin{array}{l}0.8 \\
1.2\end{array}$ & $\begin{array}{c}1 \\
1.5\end{array}$ & $\begin{array}{l}1 \\
2 \\
\end{array}$ & $\begin{array}{l}3 \\
6 \\
\end{array}$ \\
\hline Oil tankers & Loading arms & $3.0^{3}$ & 3.0 & & & & \\
\hline
\end{tabular}

Note: Motions refer to peak - peak values (except for sway: zero - peak)

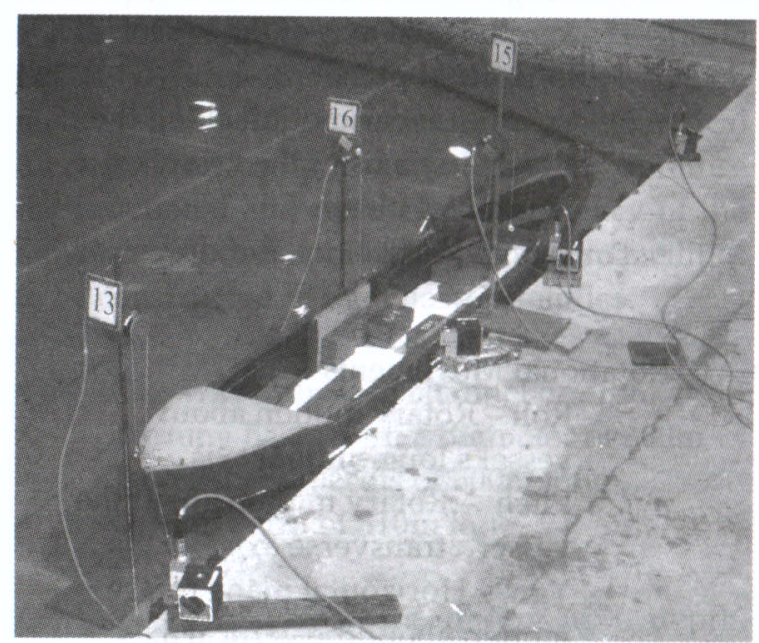

Figure 4 - Ship Movement Meters

The motions of the model ships were measured using 'Ship Movement Meter 103E' developed by the DHI Water and Environment, Denmark. Figure 4 shows the arrangement of ship movement meters for vertical movements. The PIANC (1995) criteria for acceptable movements of moored ships in harbours for safe working conditions are given in Table 2[4].

\subsection{Paddle Calibration}

The wave paddles were calibrated for each wave direction prior to the construction of breakwaters (Figure 5). This is to ensure that the waves are fully developed to the required wave spectrum a short distance away from the wave paddles. The wave generators used in the model tests were capable of generating irregular wave fields according to the JONSWAP spectrum for specified significant wave heights and peak wave periods. Wave conditions simulated in the model were derived from detailed mathematical model simulations of wave climate using MIKE 21 NSW model [3].

\section{Model Tests}

Prior to commence the actual test programme planned for the proposed model study, several test runs were carried out in order to make sure that all measuring equipments and data acquisition system were in order. It was suggested to simulate each model run for a period of $25 \mathrm{~min}$, which includes $5 \mathrm{~min}$ of stabilization period and remaining $20 \mathrm{~min}$ for data acquisition. A 20min running time in the model approximately represents $3.3 \mathrm{hrs}$ in the prototype.

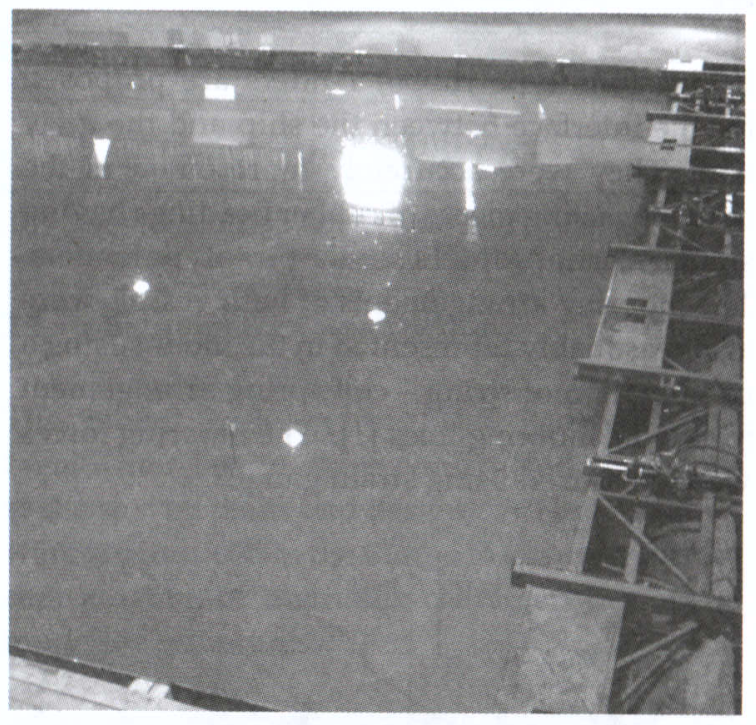

Figure 5 - Calibration of Wave Paddles

Having statistically analysed field collected wave data for more than one year, four dominant representative directions are derived. For evaluating wave disturbance inside the harbour, waves were generated from those four directions, i.e. $120^{\circ}, 150^{\circ}, 180^{\circ}$ and $210^{\circ}$ as shown if Figure 6. The wave heights were measured using 16 number of conductivity type wave gauges. These gauge stations are also shown in the figure. Table 3 gives the representative values for Significant Wave Height (Hs), Peak 
Wave Period (Tp) and \% exceedance of $25 \%$ and $2 \%$ for harbour operational condition. For each wave condition, the output parameters of $\mathrm{Hs}$ and $\mathrm{Tp}$ were measured and analysed for all wave gauge stations.

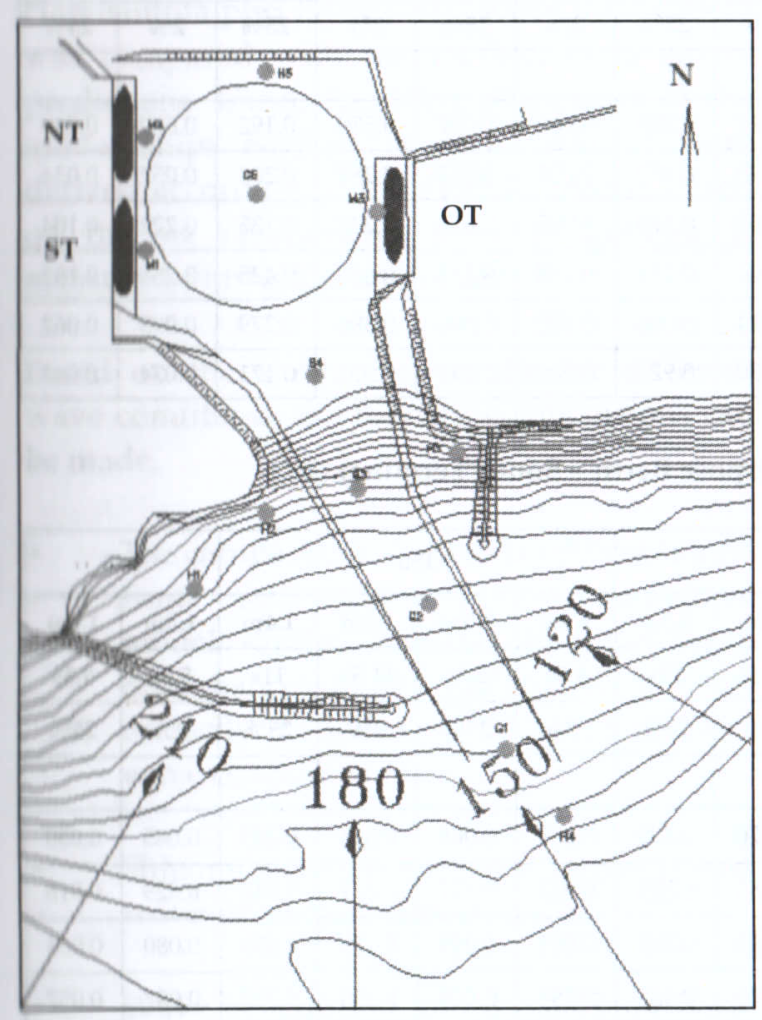

Figure 6 - Wave Directions \& Gauge Stations

There were three ship berths as shown in Figure 6. Wave conditions in Table 3 were simulated for each berth separately and ship movements were measured using movement gauges.

\section{Results and Discussion}

The results for wave disturbance in the harbour basin were compared with the mathematical model predictions using MIKE $21 \mathrm{BW}$ model (Figure 7). Reasonably good agreement was observed for wave heights measured in the harbour basin with those predicted by the mathematical model for all wave conditions. High wave penetration into the harbour basin was noted for the waves approaching from 150o direction since the channel is directly exposed to this direction.
Table 3 - Input Wave Conditions for Model Test

\begin{tabular}{|c|c|c|c|c|}
\hline \multirow{2}{*}{$\begin{array}{c}\text { Wave } \\
\text { Direction } \\
\text { (in degrees) }\end{array}$} & \multicolumn{4}{|c|}{ Percentage of Exceedence } \\
\cline { 2 - 5 } & \multicolumn{2}{|c|}{$\mathbf{2 5 \%}$} & \multicolumn{2}{c|}{$\mathbf{2 \%}$} \\
\cline { 2 - 5 } & Hs (m) & Tp (s) & Hs (m) & Tp (s) \\
\hline 210 swell & 1.4 & 12 & 2.1 & 13.5 \\
\hline 210 sea & 1.1 & 5.5 & 1.7 & 5.5 \\
\hline 180 swell & 1.5 & 12 & 2.1 & 13.5 \\
\hline 180 sea & 1.0 & 5.5 & 1.5 & 5.5 \\
\hline 150 swell & 1.4 & 11 & 1.9 & 11.5 \\
\hline 150 sea & 1.0 & 5.5 & 1.5 & 5.5 \\
\hline 120 sea & 1.0 & 5.5 & 1.5 & 5.5 \\
\hline
\end{tabular}

The ship movements were computed using the data recorded from movement meters during each model run. Six ship movements were then calculated according to the given equations from (3) to (7). These were compared with the PIANC criteria (Table 2)

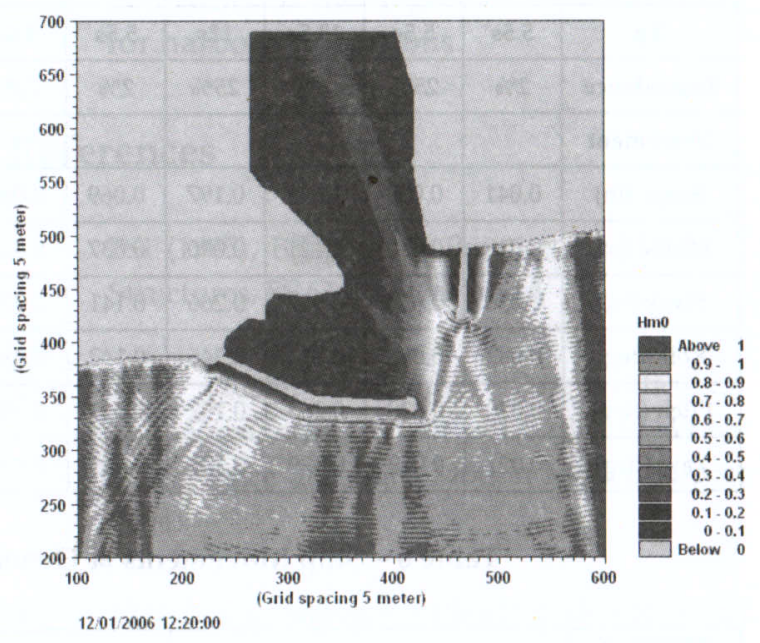

Figure 7 - Mathematical Model Simulation

for acceptable movements of moored ships in harbours for safe working conditions [4].

Ship movement results for three terminals, shown in Figure 6, (Oil Terminal-OT, General Purpose Berth South Terminal-ST, and General Purpose Berth North Terminal-NT) are given in Table 4, Table 5 \& Table 6 respectively. Movements higher than the recommended values are shaded. All movement values at OT are much smaller than the corresponding threshold values given in Table 2 . The OT is almost sheltered for direct wave attack. This could also be justified as the wave heights measured at this quay wall are smaller than those obtained at the west quay wall. Almost all movements are below the limits at NT except surge and sway. The surge and sway movements of the vessel resulting from swell waves $(\mathrm{Tp}=$ $13.5 \mathrm{~s})$ approaching from $180^{\circ}$ direction are much higher than the recommended values. This phenomenon is common for ST as well. In addition, heave movement at ST for swell waves $(\mathrm{T} p=13.5 \mathrm{~s})$ approaching from $210^{\circ}$ wave direction is also slightly exceeding the threshold condition. However as a whole, the movements of the cargo vessel for wave directions $210^{\circ}, 150^{\circ}$ and $120^{\circ}$ are smaller than the limiting values recommended by PIANC (1995) as given in Table 2. 
Table 4 - Ship Movement Values at Oil Terminal (OT)

\begin{tabular}{|c|c|c|c|c|c|c|c|c|c|c|c|c|c|c|}
\hline \multirow{2}{*}{$\begin{array}{c}\begin{array}{c}\text { Direction } \\
\text { (deg) }\end{array} \\
\mathrm{Hs} \\
\end{array}$} & \multicolumn{4}{|c|}{210} & \multicolumn{4}{|c|}{180} & \multicolumn{4}{|c|}{150} & \multicolumn{2}{|c|}{120} \\
\hline & $1.7 \mathrm{~m}$ & $1.1 \mathrm{~m}$ & $2.1 \mathrm{~m}$ & $1.4 \mathrm{~m}$ & $1.5 \mathrm{~m}$ & $1.0 \mathrm{~m}$ & $2.1 \mathrm{~m}$ & $1.5 \mathrm{~m}$ & $1.5 \mathrm{~m}$ & $1.9 \mathrm{~m}$ & $1.0 \mathrm{~m}$ & $1.4 \mathrm{~m}$ & $1.5 \mathrm{~m}$ & $1.0 \mathrm{~m}$ \\
\hline $\mathrm{Tp}$ & $5.5 \mathrm{~s}$ & $5.5 \mathrm{~s}$ & $13.5 \mathrm{~s}$ & $12 \mathrm{~s}$ & $5.5 \mathrm{~s}$ & $5.5 \mathrm{~s}$ & $13.5 \mathrm{~s}$ & $12 \mathrm{~s}$ & $5.5 \mathrm{~s}$ & $5.5 \mathrm{~s}$ & $11.5 \mathrm{~s}$ & $11 \mathrm{~s}$ & $5.5 \mathrm{~s}$ & $5.5 \mathrm{~s}$ \\
\hline Exceedence & $2 \%$ & $25 \%$ & $2 \%$ & $25 \%$ & $2 \%$ & $25 \%$ & $2 \%$ & $25 \%$ & $2 \%$ & $25 \%$ & $2 \%$ & $25 \%$ & $2 \%$ & $25 \%$ \\
\hline \multicolumn{15}{|l|}{ Movement } \\
\hline Surge $(\mathrm{m})$ & 0.061 & 0.232 & 0.391 & 0.133 & 0.051 & 0.025 & 1.417 & 0.225 & 0.069 & 0.057 & 0.510 & 0.192 & 0.080 & 0.039 \\
\hline Heave (m) & 0.023 & 0.047 & 0.100 & 0.050 & 0.020 & 0.015 & 0.173 & 0.070 & 0.058 & 0.057 & 0.287 & 0.208 & 0.052 & 0.034 \\
\hline Sway (m) & 0.047 & 0.081 & 0.231 & 0.095 & 0.027 & 0.022 & 0.502 & 0.118 & 0.095 & 0.076 & 0.232 & 0.135 & 0.222 & 0.104 \\
\hline Roll (deg) & 0.060 & 0.229 & 0.265 & 0.122 & 0.061 & 0.047 & 0.340 & 0.156 & 0.158 & 0.165 & 0.666 & 0.425 & 0.288 & 0.183 \\
\hline Pitch (deg) & 0.023 & 0.625 & 0.121 & 0.061 & 0.021 & 0.018 & 0.214 & 0.096 & 0.102 & 0.093 & 0.396 & 0.279 & 0.093 & 0.062 \\
\hline Yaw (deg) & 0.049 & 0.063 & 0.257 & 0.114 & 0.021 & 0.015 & 0.430 & 0.924 & 0.109 & 0.089 & 0.301 & 0.171 & 0.074 & 0.043 \\
\hline
\end{tabular}

Table 5 - Ship Movements at General Purpose Berth - South Terminal (ST)

\begin{tabular}{|c|c|c|c|c|c|c|c|c|c|c|c|c|c|c|}
\hline \multirow{2}{*}{$\begin{array}{c}\begin{array}{c}\text { Direction } \\
\text { (deg) }\end{array} \\
\mathrm{Hs}\end{array}$} & \multicolumn{4}{|c|}{210} & \multicolumn{4}{|c|}{180} & \multicolumn{4}{|c|}{150} & \multicolumn{2}{|c|}{120} \\
\hline & $1.7 \mathrm{~m}$ & $1.1 \mathrm{~m}$ & $2.1 \mathrm{~m}$ & $1.4 \mathrm{~m}$ & $1.5 \mathrm{~m}$ & $1.0 \mathrm{~m}$ & $2.1 \mathrm{~m}$ & $1.5 \mathrm{~m}$ & $1.5 \mathrm{~m}$ & $1.9 \mathrm{~m}$ & $1.0 \mathrm{~m}$ & $1.4 \mathrm{~m}$ & $1.5 \mathrm{~m}$ & $1.0 \mathrm{~m}$ \\
\hline $\mathrm{Tp}$ & $5.5 \mathrm{~s}$ & $5.5 \mathrm{~s}$ & $13.5 \mathrm{~s}$ & $12 \mathrm{~s}$ & $5.5 \mathrm{~s}$ & $5.5 \mathrm{~s}$ & $13.5 \mathrm{~s}$ & $12 \mathrm{~s}$ & $5.5 \mathrm{~s}$ & $5.5 \mathrm{~s}$ & $11.5 \mathrm{~s}$ & $11 \mathrm{~s}$ & $5.5 \mathrm{~s}$ & $5.5 \mathrm{~s}$ \\
\hline Exceedence & $2 \%$ & $25 \%$ & $2 \%$ & $25 \%$ & $2 \%$ & $25 \%$ & $2 \%$ & $25 \%$ & $2 \%$ & $25 \%$ & $2 \%$ & $25 \%$ & $2 \%$ & $25 \%$ \\
\hline \multicolumn{15}{|l|}{ Movement } \\
\hline Surge (m) & 0.041 & $0.033^{\circ}$ & 1.643 & 0.197 & 0.069 & 0.059 & 2.070 & 0.492 & 0.059 & 0.068 & 0.618 & 0.215 & 0.085 & 0.050 \\
\hline Heave (m) & 0.019 & 0.016 & 1.121 & 0.090 & 0.037 & 0.027 & 0.255 & 0.228 & 0.023 & 0.017 & 0.071 & 0.044 & 0.029 & 0.018 \\
\hline Sway (m) & 0.036 & 0.030 & 0.917 & 0.266 & 0.141 & 0.078 & 1.865 & 0.763 & 0.035 & 0.025 & 0.179 & 0.076 & 0.080 & 0.053 \\
\hline Roll (deg) & 0.083 & 0.088 & 0.711 & 0.346 & 0.142 & 0.085 & 1.170 & 0.668 & 0.088 & 0.056 & 0.336 & 0.213 & 0.087 & 0.057 \\
\hline Pitch (deg) & 0.020 & 0.020 & 0.263 & 0.197 & 0.047 & 0.033 & 0.542 & 0.406 & 0.014 & 0.017 & 0.100 & 0.058 & 0.029 & 0.018 \\
\hline Yaw (deg) & 0.021 & 0.017 & 0.329 & 0.103 & 0.045 & 0.037 & 0.568 & 0.230 & 0.017 & 0.016 & 0.151 & 0.058 & 0.020 & 0.013 \\
\hline
\end{tabular}

Table 6 - Ship Movements at General Purpose Berth - North Terminal (NT)

\begin{tabular}{|c|c|c|c|c|c|c|c|c|c|c|c|c|c|c|}
\hline \multirow{2}{*}{$\begin{array}{c}\begin{array}{c}\text { Direction } \\
\text { (deg) }\end{array} \\
\text { Hs }\end{array}$} & \multicolumn{4}{|c|}{210} & \multicolumn{4}{|c|}{180} & \multicolumn{4}{|c|}{150} & \multicolumn{2}{|c|}{120} \\
\hline & $1.7 \mathrm{~m}$ & $1.1 \mathrm{~m}$ & $2.1 \mathrm{~m}$ & $1.4 \mathrm{~m}$ & $1.5 \mathrm{~m}$ & $1.0 \mathrm{~m}$ & $2.1 \mathrm{~m}$ & $1.5 \mathrm{~m}$ & $1.5 \mathrm{~m}$ & $1.9 \mathrm{~m}$ & $1.0 \mathrm{~m}$ & $1.4 \mathrm{~m}$ & $1.5 \mathrm{~m}$ & $1.0 \mathrm{~m}$ \\
\hline $\mathrm{Tp}$ & $5.5 \mathrm{~s}$ & $5.5 \mathrm{~s}$ & $13.5 \mathrm{~s}$ & $12 \mathrm{~s}$ & $5.5 \mathrm{~s}$ & $5.5 \mathrm{~s}$ & $13.5 \mathrm{~s}$ & $12 \mathrm{~s}$ & $5.5 \mathrm{~s}$ & $5.5 \mathrm{~s}$ & $11.5 \mathrm{~s}$ & $11 \mathrm{~s}$ & $5.5 \mathrm{~s}$ & $5.5 \mathrm{~s}$ \\
\hline Exceedence & $2 \%$ & $25 \%$ & $2 \%$ & $25 \%$ & $2 \%$ & $25 \%$ & $2 \%$ & $25 \%$ & $2 \%$ & $25 \%$ & $2 \%$ & $25 \%$ & $2 \%$ & $25 \%$ \\
\hline \multicolumn{15}{|l|}{ Movement } \\
\hline Surge (m) & 0.045 & 0.038 & 1.128 & 0.278 & 0.052 & 0.048 & 2.882 & 0.630 & 0.069 & 0.041 & 0.659 & 0.038 & 0.062 & 0.037 \\
\hline Heave (m) & 0.022 & 0.016 & 0.118 & 0.077 & 0.029 & 0.067 & 0.269 & 0.132 & 0.039 & 0.032 & 0.263 & 0.029 & 0.036 & 0.026 \\
\hline Sway (m) & 0.057 & 0.053 & 0.802 & 0.298 & 0.119 & 0.022 & 2.320 & 1.034 & 0.093 & 0.065 & 0.587 & 0.060 & 0.074 & 0.050 \\
\hline Roll (deg) & 0.097 & 0.068 & 0.577 & 0.317 & 0.109 & 0.155 & 0.990 & 0.597 & 0.146 & 0.107 & 0.798 & 0.099 & 0.149 & 0.099 \\
\hline Pitch (deg) & 0.022 & 0.021 & 0.217 & 0.152 & 0.046 & 0.047 & 0.577 & 0.389 & 0.046 & 0.034 & 0.283 & 0.032 & 0.053 & 0.042 \\
\hline Yaw (deg) & 0.075 & 0.069 & 1.004 & 0.368 & 0.031 & 0.012 & 0.675 & 0.254 & 0.048 & 0.029 & 0.208 & 0.027 & 0.049 & 0.032 \\
\hline
\end{tabular}

However, in cases where movements are exceeding the recommended values, these excessive translatory movements can be controlled by providing additional mooring cables during these events. Ship motions at the general purpose terminal were larger than those at the oil terminal for all tested wave conditions, as the cargo operations at general terminal were affected by longer period waves and it results for high sway and yaw movements. 


\section{Conclusion}

A comprehensive 3D physical model study was carried out in order to assess the wave disturbance and ship motion for the proposed Hambantota port layout. The wave disturbance was compared with the mathematical model predictions. Cargo handling efficiencies of the model ships berthed at each terminal were derived according to the PIANC criteria based on the six components of ship movements measured during the model tests.

Based on the simulation results for different wave conditions, the following conclusions can be made,

*

The comparison of wave heights obtained from both physical and numerical model studies confirms that the wave disturbances in the harbour basin were correctly modelled for the given incident wave conditions.

- Ship movement is greater in longer period waves than shorter period waves.

- Wave penetration into the harbour basin was somewhat low for short period waves particularly 5.5 sec wave and hence, ship movements for $5.5 \mathrm{sec}$ waves might have been underestimated. However, the actual vessel movements for $5.5 \mathrm{sec}$ waves are smaller than that obtained for swell waves and most of these movements are smaller than the limiting values for safe cargo operations, and hence, it can be argued that the ship movements for short period waves are not that significant for disruption of harbour operations.

- Wave disturbance and ship movements are generally high at the west quay wall than at the east quay wall.

- Disturbances to cargo handling due to high sway surge and heave movements observed in few long period wave conditions could be reduced by improving the mooring system. Therefore, few additional cables can be used to moor the ship only during high wave conditions without seriously disrupting cargo operations.
As for further conclusion on harbour siltation, a mathematical model study for hydrodynamic and sediment transport pattern of the inner harbour and its vicinity was carried out by LHI. According to that report following remarks can be drawn [5], even though this part is beyond the scope of this paper.

- $\quad$ Sediment transportrates across the channel are much higher for swell wave conditions propagating along SW direction.

- There would be an infill volume of about $20,000 \mathrm{~m} 3 / \mathrm{yr}$ across the channel.

- The net sediment transport rate across the harbour entrance is about $400 \mathrm{~m} 3 / \mathrm{yr}$.

- Dredging frequency would be determined according to the degree of siltation effect for harbour operations.

\section{References}

1. BSI (1985), BS Code of Practice for Maritime Structures, BS 6349 : Part 1 and 4

2. LHI (2005), Colombo Port Efficiency and Expansion Project: 3D (Basin) Wave Disturbance and Ship Motion Model, Report 0404.

3. LHI (2007), Hambantota Sea Port Development - Phase I Project: Mathematical Model Test on Wave Field, Report 0610.

4. PIANC (1995), Criteria for Movements of Moored Ships in Harbours: A Practical Guide, Bulletin 88

5. LHI (2007), Hambantota Sea Port Development - Phase I Project: Mathematical Model Test on Hydrody- namic and Sediment transport Modelling, Report 0610

6. Robert A. Dalrymple(1985), Physical Modelling in Coastal Engineering, A.A.Balkema, Netherlands 